\title{
ENVIRONMENTAL PERCEPTION ABOUT MARINE AND COASTAL ECOSYSTEMS: EVALUATION THROUGH A RESEARCH INSTRUMENT BASED ON MODEL OF ECOLOGICAL VALUES
}

\author{
Suzana Ursi, Naomi Towata \\ University of São Paulo, Brazil \\ E-mail: suzanaursi@usp.br, ntowata@usp.br
}

\begin{abstract}
The first aim of research is to propose a research instrument based on Wiseman and Bogner's Model of Ecological Values, the "Coastal Environment Questionnaire" (CEQ), specifically developed to evaluate the Environmental Perception about marine and coastal ecosystems. The second aim is to explore, using $C E Q$, the position on the categories from Model of Ecological Values of some basic education students and some pre-service biology teachers from cities located near coastal areas from Brazil. CEQ was modified from "The Environment Questionnaire" (TEQ), which consists of a questionnaire composed of 16 items with Likert-type responses. The first process to have elaborated the new instrument changed the general situations described in the items of TEQ (most related with land environments) to situations related to marine and coastal environments. CEQ has been used with: 63 pre-service biology teachers from a non-coastal city; 79 basic education students from a non-coastal city; and 74 basic education students from a coastal city. All pre-service teachers were placed at Preservation+Utilization-category (100\%). However, most students were placed at the Preservation+Utilization-category (around 70\%), followed by Preservation+Utilization+ (around 25\%), regardless their city location. It is expected that CEQ can be useful on research aim to better understand the perception about marine and coastal environments, contributing to development and evaluation of future Environmental Educational program focus on these important ecosystems.
\end{abstract}

Keywords: basic education students, Coastal Environment Questionnaire (CEQ), environmental perception, Model of Ecological Value, pre-service biology teachers.

\section{Introduction}

Different people may have completely different reactions to the same environment. Therefore, the relevance of studies focus on Environmental Perception (EP) is notorious. It is important to know this perception to plan actions aiming to increase population knowledge about the ecological, economic and social importance of distinct environments. In this way, White (1977) recognized EP as a fundamental step for development and improvement of Environmental Education programs.

Although there is not a consensus about EP concept, due to its complexity, it can be considered that there are relations between the individual and the environment which occur through perceptual and cognitive mechanisms (Bell, Greene, Fisher \& Baum, 2001). Environmental values and attitudes are also an important part of EP. These attitudes may 
Suzana URSI, Naomi TOWATA. Environmental perception about marine and coastal ecosystems: Evaluation through a research instrument based on model of ecological values

PROBLEMS

OF EDUCATION

IN THE $21^{\text {st }}$ CENTURY Vol. 76, No. 3, 2018

be defined as the collection of beliefs and behavioral intentions a person holds regarding environmentally related activities or issues (Schultz, Shriver, Tabanico \& Khazian, 2004).

According to Johnson and Manoli (2008), a lot of studies about EP (and the related ideas of attitudes, concern, beliefs, paradigms, values and worldviews) have been conducted since the emergence of New Environmental Paradigm (Dunlap, 1975) and these studies attempted to get at something similar: how people view the natural environment and the place of humans within it. Dunlap, Van Liere, Mertig and Jones (2000) understand EP as a unidimensional construction. As a consequence, some of the most emblematic approaches in this research area aim to understand how individuals are distributed on a Biocentric (pro-environmental) to an Anthropocentric (anti-environmental) continuum (Figure 1).

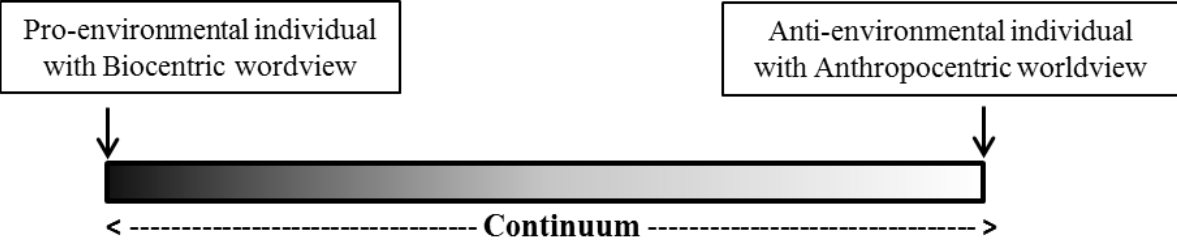

Figure 1: Representation of a unidimensional model of Environmental Perception.

The Model of Ecological Values (Wiseman \& Bogner, 2003) can be considered an evolution of this approach, which has a two-dimensional nature:

"Ecological Values are determined by one's position on two orthogonal dimensions, a biocentric dimension that reflects conservation and protection of the environment (Preservation); and an anthropocentric dimension that reflects the utilization of natural resources (Utilization)" (Figure 2).

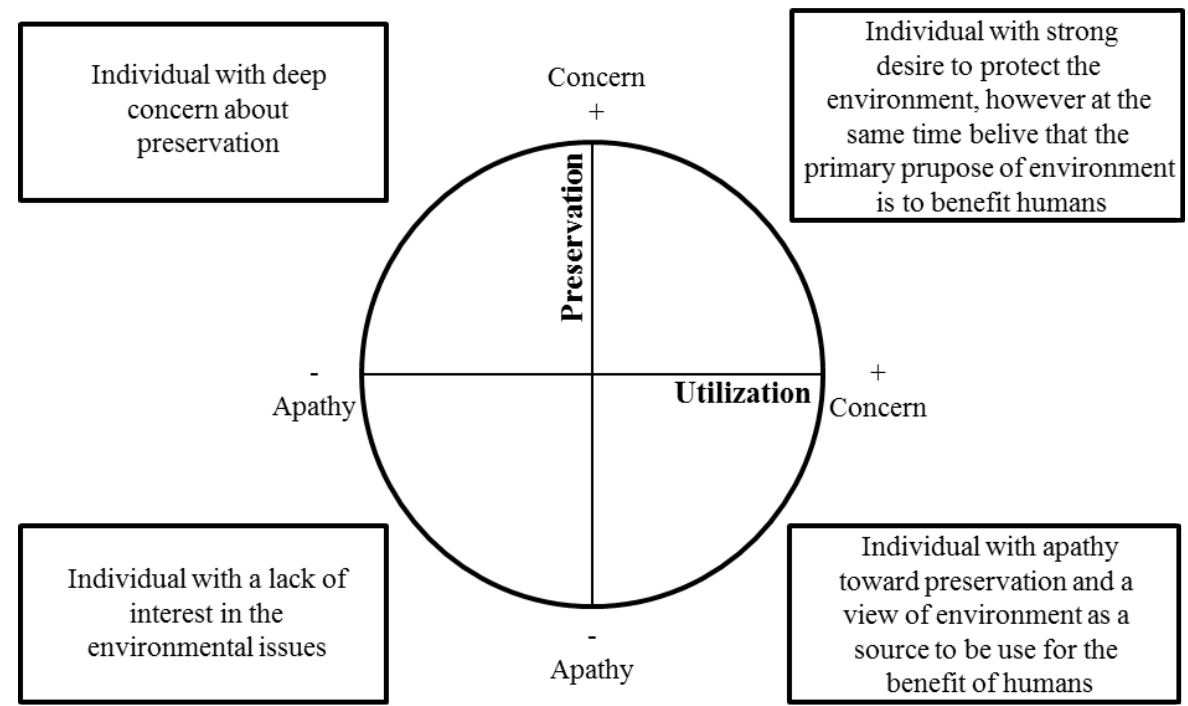

Figure 2: Representation of a two-dimensional model of Environmental Perception. (Adapted from Wiseman and Bogner, 2003).

The model of Ecological Values postulates that Preservation (P) and Utilization (U) are two important, but not necessarily related components of EP. It allows individuals to be placed in one of four Cartesian quadrants (Figure 2): 
- $\quad \mathrm{P}+\mathrm{U}-$ position might be expected from a strong environmentalist, someone with

deep concern about conservation;

- $\quad$ P-U+ position might be expected from someone with apathy toward conservation issues and a view of nature as a source of natural resources to be used for the benefit of human development;

- $\quad \mathrm{P}+\mathrm{U}+$ position might be expected from someone with a strong desire to protect the environment, but at the same time believe that the primary purpose of nature is to benefit humans;

- $\quad$ P-U- position might be expected from someone with a lack of interest in the environmental issues.

The $\mathrm{P}+\mathrm{U}-$ and $\mathrm{P}-\mathrm{U}+$ quadrants (Figure 2) are the ends of the Biocentric-Anthropocentric continuum (Figure 1). Individuals in the $\mathrm{P}+\mathrm{U}+$ quadrant would likely be placed in the center of this continuum, leading to a misinterpretation of their perceptions as noncommittal when in reality their views might be quite strong. However, P-U- position is most likely indicative that such individuals would most likely also, but more appropriately, be placed in the middle of the Biocentric-Anthropocentric continuum (Johnson \& Manoli, 2008).

The Wiseman and Bogner's Model of Ecological Values were postulated based on empirical research using different versions of a measurement instrument. Frist, Bogner and Wilhelm (1996) developed a questionnaire which consists of an extensive list of 69 items with Likert-type responses, the "Two-dimensional Model of Ecological Value Scale" (2-MEV). A series of studies reduced the initial set to 19 items (Bogner \& Wiseman, 1997a; 1997b; 1998; 1999). In 1999, Bogner and Wiseman enhanced 2-MEV and the items were grouped into 2 secondary factors: Preservation (composed by 3 primary factors - intent of support, care with resources, and enjoyment of nature) and Utilization (composed by 2 primary factors - altering nature, human dominance). More recently, Johnson and Manoli (2008) modified 2-MEV and developed "The Environment Questionnaire" (TEQ), with 16 items. Both instruments have been applied to evaluate the influence of educational programs on EP from students (ex. Bogner, 1999; 2002; Bogner \& Wiseman, 1999; 2004; Johnson and Manoli, 2008; 2011) or from teachers (Munoza, Bogner, Clement \& Carvalho, 2009). Most of situations presented on the 2-MEV and TEQ items are related to land environments.

Despite their relevance, marine and coastal ecosystems are sometimes overlooked on EP discussions based on an apparent distance between them and people's daily lives (Towata \& Ursi, 2017). It could not be found on literature any research instrument based on Model of Ecological Values focused specially on marine and coastal ecosystems. Then, a modification of TEQ could be a good alternative to investigate specifically the EP about these important environments.

Coastal zones are at the complex and dynamic interface between the land and the sea, and are occupied by dense human populations, many living in rapidly growing mega-cities (Michael, Post, Wilson \& Werner, 2017). Coastal and marine environments have been suffering several damages due to this population growth, pollution and other human activities (e.g. temperature change, increased acidity, decreased oxygen level, habitat destruction) (Barbier, 2017; Fauville, 2017; Ludin \& Lindén, 1993). It is notorious that human beings have been polluted by coastal and marine environments in many different ways (e.g. oil, plastic, toxic substances) (Fox, O'Hara, Bertazzon, Morgan, Underwood \& Paquet, 2016; Nel, Hean, Noundou \& Froneman, 2016), as well as overexploited their resources (Rubio-Cisneros, Aburto-Oropeza, Jackson \& Ezcurra, 2017; Rustici, Ceccherelli \& Piazzi, 2017). According to Barbier (2017), 50\% of salt marches, $35 \%$ of mangroves, $30 \%$ of coral reefs, and $29 \%$ of seagrasses have already been lost or degraded worldwide over several decades. Therefore, essential areas for ocean organisms to survive have been degraded, like the mangroves areas that are considered a nursery for fishes and this would have a huge impact on fish populations (Sheaves, 2017; Tran \& Fischer, 2017). 
Suzana URSI, Naomi TOWATA. Environmental perception about marine and coastal ecosystems: Evaluation through a research instrument based on model of ecological values

\section{PROBLEMS \\ OF EDUCATION \\ IN THE $21^{\text {st }}$ CENTURY Vol. 76, No. 3, 2018 \\ 396}

Uyarra and Borja (2016) highlight that the scientific community need to first understand both how people influence the oceans and how the oceans influence people, as well as how a better understanding of the human-ocean relationship translates into a behavioral change that positively affects the oceans. In this perspective, the knowledge about EP related to marine and coastal environments is an important step for their conservation, even though there are few studies about it when compared to the ones that focus on land ecosystems, especially in Brazil.

The research about EP on marine and coastal environments mainly focus on tourist's perception about environment conservation or degradation (e.g. Krelling, Williams \& Turra, 2017; Pedrini, Brotto, Lopez, Ferreira \& Guilardi-Lopez, 2013); perception of risk (e.g. Aswani, Vaccaro, Abernethy, Albert \& Pablo, 2015; Covi \& Kain, 2015; Jacobs, Sioen, Pieniak, Henauw, Maulyault, Reuver, Fait, Cano-Sancho \& Verbeke, 2015); perception of local residents, stakeholders or tourists about environmental changes (e.g. De Juan; Gelcich \& Fernandez, 2017; Ghilardi-Lopes, Turra, Buckeridge, Silva, Berchez \& Oliveira, 2015; Yasué, Kaufman \& Vincent, 2010); and student's general perception about these environments (e.g. Katon, Towata, Berchez, Oliveira \& Ursi, 2013; Katon, Towata, Berchez \& Ursi, 2014; Towata \& Ursi, 2017).

Therefore, the aims of this research are: (1) to propose a research instrument based on Wiseman and Bogner's Model of Ecological Values, the "Coastal Environment Questionnaire" (CEQ), specifically developed from a TEQ modification to evaluate the Environmental Perception about marine and coastal ecosystems; (2) to evaluate, using CEQ, the position on the categories from Model of Ecological Values of some basic education students and some pre-service biology teachers from cities located near coastal areas from Brazil. The following research questions were formulated with regard to the research purposes:

- $\quad$ Is CEQ a useful research instrument to evaluate ecological values about marine and coastal ecosystems?

- $\quad$ Are there differences of the positions on the categories from Model of Ecological Values among the subject groups focused on this research?

\section{Methodology of Research}

\section{General Background}

The conducted research was part of the project entitled "Environmental Perception and Biodiversity: development and evaluation of didactic activities in marine and coastal environments" (EP\&B), supported by the BIOTA-FAPESP Program.

This program was created in 1999 and aimed not only at discovering, mapping and analyzing the origins, diversity and distribution of the flora and fauna of the State of São Paulo (Brazil), but also at evaluating the possibilities of sustainable exploitation of plants or animals with economic potential and assisting in the formulation of conservation policies on forest remnants. BIOTA-FAPESP Program has been called the Virtual Institute of Biodiversity owing to the form of its organization, integrating researchers from several institutions and their students. Scientists from the leading public universities in the state of São Paulo, research institutes and non-governmental organizations participate in projects to discover, map and analyze the biodiversity distributed in land and marine environments and in other ecosystems, as well as proposing alternatives and public policies to preserve it. The program involves around 1,200 professionals (http://www.biota.org.br). Other goal is to produce science dissemination and didactic materials/activities based on the research results of the program.

In this context, it was relevant to evaluate the possible influences of these materials/ activities on EP of students and teachers. It was one of the aims of EP\&B project. Most of the conducted evaluations of this project had a qualitative or a mix approach (e.g. Savietto, Katon, 
Suzana URSI, Naomi TOWATA. Environmental perception about marine and coastal ecosystems: Evaluation through a research instrument based on model of ecological values

Towata, Berchez \& Ursi, 2014; Ursi, Towata, Saito, Barbosa, Macedo, Viana \& Berchez, 2016). However, to a larger scale research, a quantitative instrument was necessary. It could not be found on literature any research instrument based on Model of Ecological Values focused specially on EP about marine and coastal ecosystems. Then, CEQ was elaborated and an initial test was developed aiming to study if it can help on studies focus specifically on the EP of students and teachers about these important environments.

\section{Research Instrument}

The first process to be elaborated CEQ was changed the general situations described in the 16 items of TEQ to situations related to marine and coastal environments. This process was done for both dimensions: Preservation and Utilization (Tables 1-2).

Table 1. TEQ ("The Environment Questionnaire" - Johnson \& Manoli, 2008) and CEQ ("Coastal Environment Questionnaire") items for Preservation and its three primary factors.

\begin{tabular}{|c|c|}
\hline TEQ & CEQ \\
\hline \multicolumn{2}{|l|}{ Intent of support } \\
\hline $\begin{array}{l}\text { If I ever have extra money, I will give some to help } \\
\text { protect nature. }\end{array}$ & $\begin{array}{l}\text { If I ever have extra money, I will give some to help protect } \\
\text { marine and costal environments. }\end{array}$ \\
\hline I would help raise money to protect nature. & $\begin{array}{l}\text { I would help raise money to protect marine and costal } \\
\text { organisms. }\end{array}$ \\
\hline I try to tell others that nature is important. & I try to tell others that sea and costal zones are important. \\
\hline \multicolumn{2}{|l|}{ Care with resources } \\
\hline $\begin{array}{l}\text { To save energy in the winter, I make sure the heat in } \\
\text { my room is not on too high. }\end{array}$ & $\begin{array}{l}\text { I do not eat canned fish (ex. tuna, sardines), because the } \\
\text { commercial fishing net is dangerous to some marine organ- } \\
\text { isms. }\end{array}$ \\
\hline $\begin{array}{l}\text { I always turn off the light when I do not need it } \\
\text { anymore. }\end{array}$ & I collect all the trash that I produce when I go to the beach. \\
\hline $\begin{array}{l}\text { I try to save water by taking shorter showers or by } \\
\text { turning off the water when I brush my teeth. }\end{array}$ & $\begin{array}{l}\text { When I go to the beach, I do not take shells, as a souvenir, } \\
\text { to my home. }\end{array}$ \\
\hline \multicolumn{2}{|l|}{ Enjoyment of nature } \\
\hline $\begin{array}{l}\text { I would really enjoy sitting at the edge of a pond } \\
\text { watching dragonflies in flight. }\end{array}$ & $\begin{array}{l}\text { I really like to sit close to the beach and watch the living } \\
\text { beings that live in this environment. }\end{array}$ \\
\hline $\begin{array}{l}\text { I really like to be able to go on trips into the country- } \\
\text { side-for example to forests or fields. }\end{array}$ & I really like to travel to the coast. \\
\hline I feel good in the silence of nature. & I feel good listening to the ocean waves. \\
\hline
\end{tabular}


OF EDUCATION IN THE $21^{\text {st }}$ CENTURY Vol. 76, No. 3, 2018

Table 2. TEQ ("The Environment Questionnaire" - Johnson \& Manoli, 2008) and CEQ ("Coastal Environment Questionnaire") items for Utilization and its two primary factors.

\begin{tabular}{ll}
\hline TEQ & CEQ \\
\hline Altering nature & \\
\hline People have the right to change the environment. & $\begin{array}{l}\text { People have the right to change the marine and } \\
\text { coastal environments. }\end{array}$ \\
\hline $\begin{array}{l}\text { I like a grass lawn more than a place where flowers grow on } \\
\text { their own. }\end{array}$ & $\begin{array}{l}\text { I like a beach with good infrastructure (with restau- } \\
\text { rants and hotels) more than a wild beach. }\end{array}$ \\
\hline $\begin{array}{l}\text { To feed people, nature must be cleared to grow food. } \\
\text { Weeds should be killed because they take up space from } \\
\text { plants we need. }\end{array}$ & $\begin{array}{l}\text { Slimy seaweeds of seashore should be removed } \\
\text { because they take up space from other organisms } \\
\text { that we can use. }\end{array}$ \\
\hline Human dominance & $\begin{array}{l}\text { Natural marine and coastal environments should } \\
\text { be replaced by farming areas (of fish, shellfish and } \\
\text { so on) so than they would have more use for our } \\
\text { nourishment. }\end{array}$ \\
\hline $\begin{array}{l}\text { Building new roads is so important that trees should be cut } \\
\text { down. }\end{array}$ & $\begin{array}{l}\text { Building new ports are so important that some } \\
\text { coastal areas should be replaced by them. }\end{array}$ \\
\hline $\begin{array}{l}\text { Because mosquitoes live in marshes and swamps, it would } \\
\text { be better to drain these and use them for farming. }\end{array}$ & $\begin{array}{l}\text { Many insects live in wetlands (such as mangrove), } \\
\text { so it would be better to drain these and use them for } \\
\text { housing construction. }\end{array}$ \\
\hline $\begin{array}{l}\text { People are supposed to rule over the rest of nature. } \\
\text { Our species, being the most important, should } \\
\text { decide on the fate of others including marine and } \\
\text { coastal species. }\end{array}$ \\
\hline
\end{tabular}

Items in the CEQ are statements about the marine and coastal environment (Tables 1-2) with a 5-point Likert-type response set of "strongly agree", "agree", "not sure", "disagree" and "strongly disagree". CEQ scoring involved assigning points, from one point for "strongly disagree' to five points for 'strongly agree'.

\section{Participants}

CEQ was used with three different subject groups from Brazil (the same ones investigated by Towata \& Ursi, 2017). The first group (pre-service biology teachers from a non-coastal city) was formed by 63 undergraduate students from São Paulo, which is the biggest city in Brazil, located approximately $70 \mathrm{~km}$ away from the sea. They studied at São Paulo University, on an initial teacher training course of Biology, in which one of the researchers is professor. There were 36 girls and 27 boys, 17-36 age group. These pre-service teachers were participants of a discipline entitled "Strategies and Sources for Teaching Biology" or of a teacher training program entitled "Institutional Scholarship Program for Beginning Teachers" (PIBID).

The second group (students from a non-coastal city) consisted of 79 basic education students from a public school also from São Paulo city, 43 girls and 36 boys, 11-16 age group. These students were from a school were PIBID occurred.

The last group (students from a coastal city) consisted of 74 basic education students from two public schools from a coastal city (Caraguatatuba, Brazil), 51 girls and 23 boys, 13-16 age group. These students were from schools that were partners on the Environmental Educational program "Underwater Trial", in which the researchers were contributors. 
Suzana URSI, Naomi TOWATA. Environmental perception about marine and coastal ecosystems: Evaluation through a research instrument based on model of ecological values

\section{Data Collection}

Data collection took place from April 2014 to April 2016. At the schools, the students had 45 minutes to respond CEQ (period of a lesson), with the presence of one of the researchers and the class teacher. All of students were able to complete the instrument in this period. The pre-service teachers had free time to respond CEQ, during a discipline class or during a PIBID meeting. One of the researchers was presented during the process. All the pre-service teachers took less than 15 minutes to finish CEQ.

Pre-service teachers and basic education students voluntarily participated in the research after signing a written consent form and receiving information about the research goals. The school principals also signed a consent form, agreeing with the research.

\section{Data Analysis}

Items in the CEQ were grouped into factors (Tables 1-2). For each of primary and secondary factors, means were calculated, and mean scores range from 1.0 to 5.0. For Preservation and its three primary factors, mean scores between 3 and 5 indicated a proenvironmental perception $(\mathrm{P}+)$, while mean scores between 1 and 3 indicate the opposite $(\mathrm{P}-)$. The reverse is true for Utilization and its two primary factors, mean scores between 1 and 3 indicated a pro-environmental perception (U-), while mean scores between 3 and 5 indicate the opposite (U+) (Johnson \& Manoli, 2008). For each subject group, mean scores of participants were plotted on the Cartesian quadrants and the percentage of individual positions on the four categories from Model of Ecological Values were calculated (P+U-, P-U+, P+U+, P-U-).

\section{Results of Research}

The pre-service biology teachers did not have trouble to understand CEQ. In the case of students, the application was also satisfactory and only one student from a non-coastal city did not know the meaning of the word mangrove. Therefore, it can be considered that CEQ presented clarity and an appropriate language.

The analyses showed that students from a coastal city are mostly placed at $\mathrm{P}+\mathrm{U}$ - category (70\%), followed by $\mathrm{P}+\mathrm{U}+(26 \%)$ and $\mathrm{P}-\mathrm{U}-(3 \%)$. No students were placed at $\mathrm{P}-\mathrm{U}+$ quadrant (Figure 3). 
Suzana URSI, Naomi TOWATA. Environmental perception about marine and coastal ecosystems: Evaluation through a research instrument based on model of ecological values

PROBLEMS

OF EDUCATION

IN THE $21^{\text {st }}$ CENTURY

Vol. 76, No. 3, 2018

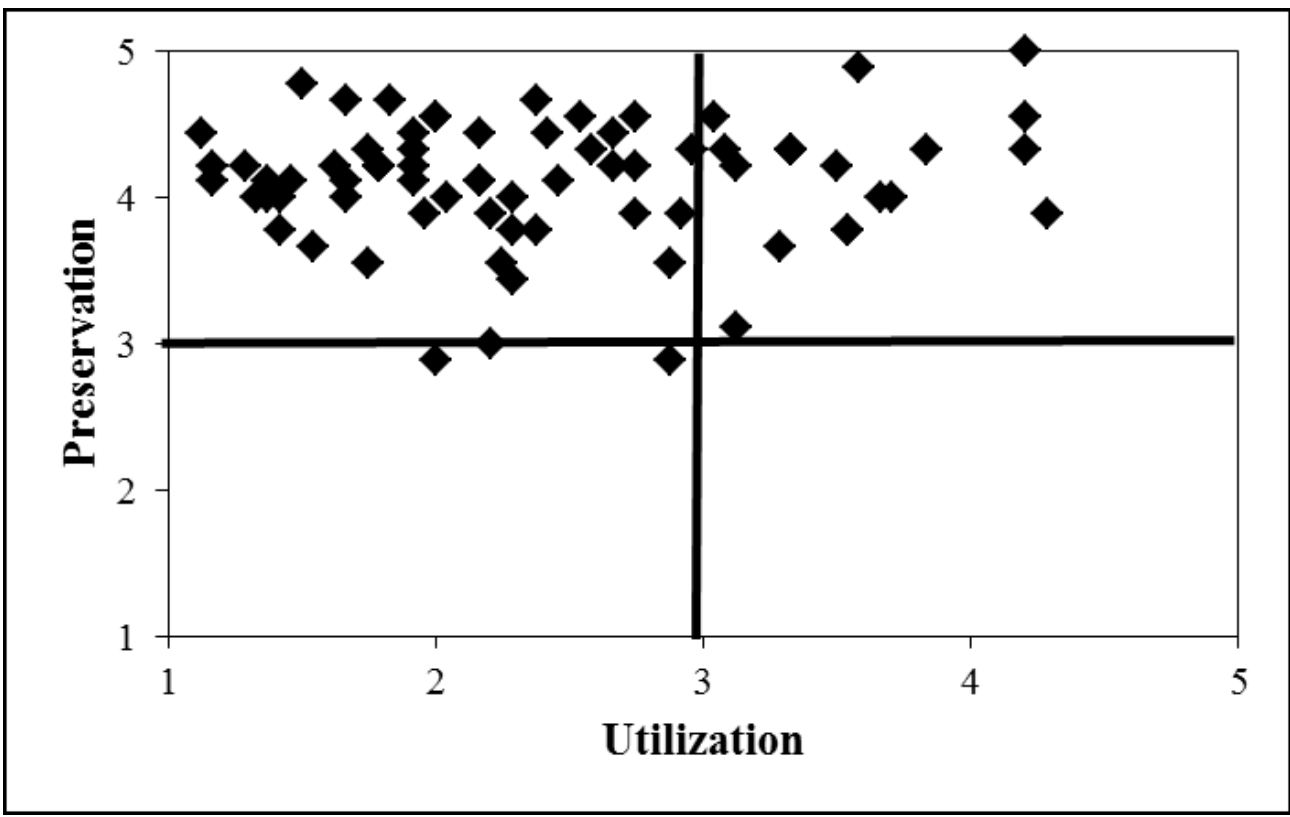

Figure 3: Model of ecological values quadrant scores for students from a coastal city (Caraguatatuba, Brazil).

Results are similar for students from a non-coastal city. $71 \%$ of them are located at $\mathrm{P}+\mathrm{U}$ category, followed by $\mathrm{P}+\mathrm{U}+(24 \%)$. However, it was detected students located at P-U+ category $(4 \%)$, in which we can classify people with apathy toward conservation issues and a view of nature as a source of natural resources. Only $1 \%$ of students were located at P-U- category (Figure 4).

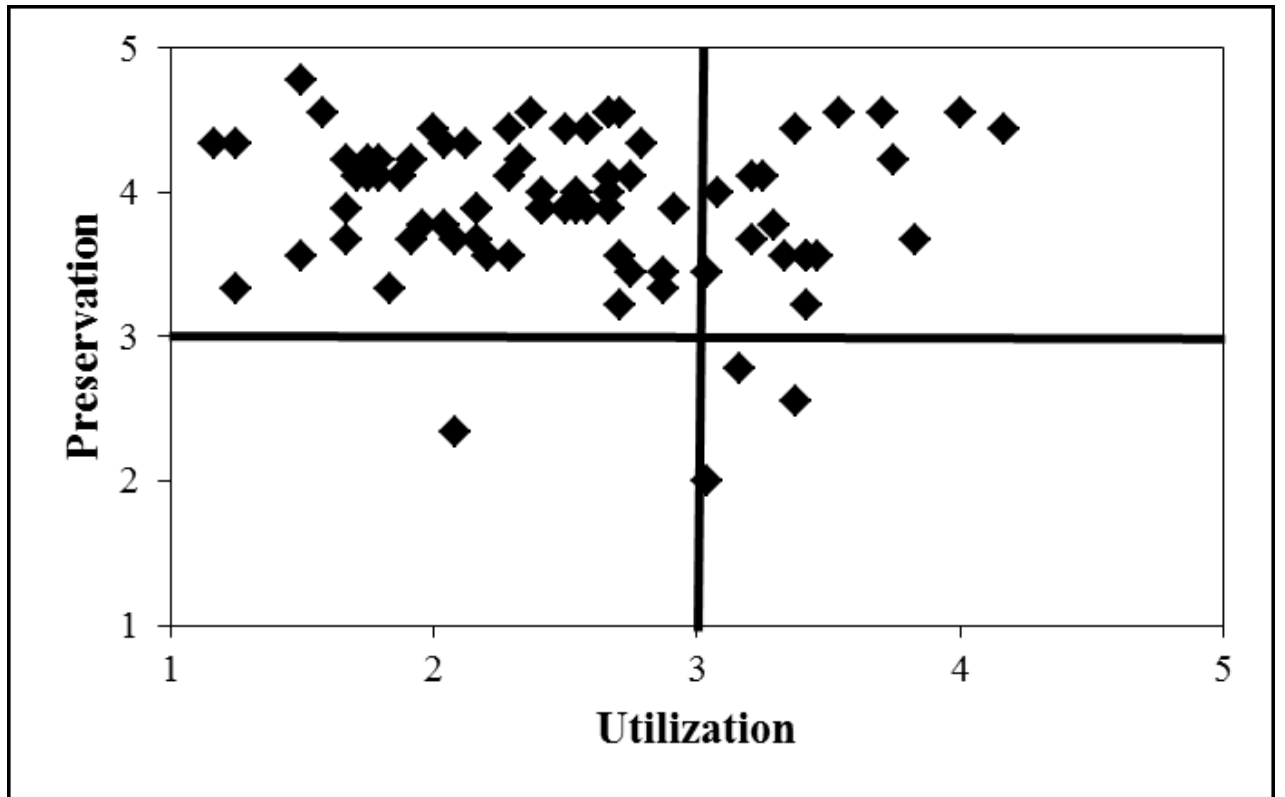

Figure 4: Model of ecological values quadrant scores for students from a noncoastal city (São Paulo, Brazil). 
Suzana URSI, Naomi TOWATA. Environmental perception about marine and coastal ecosystems: Evaluation through a research instrument based on model of ecological values

Pre-service biology teachers showed different results when compared with students, 40 since all of the teachers were placed at $\mathrm{P}+\mathrm{U}-$ (Figure 5).

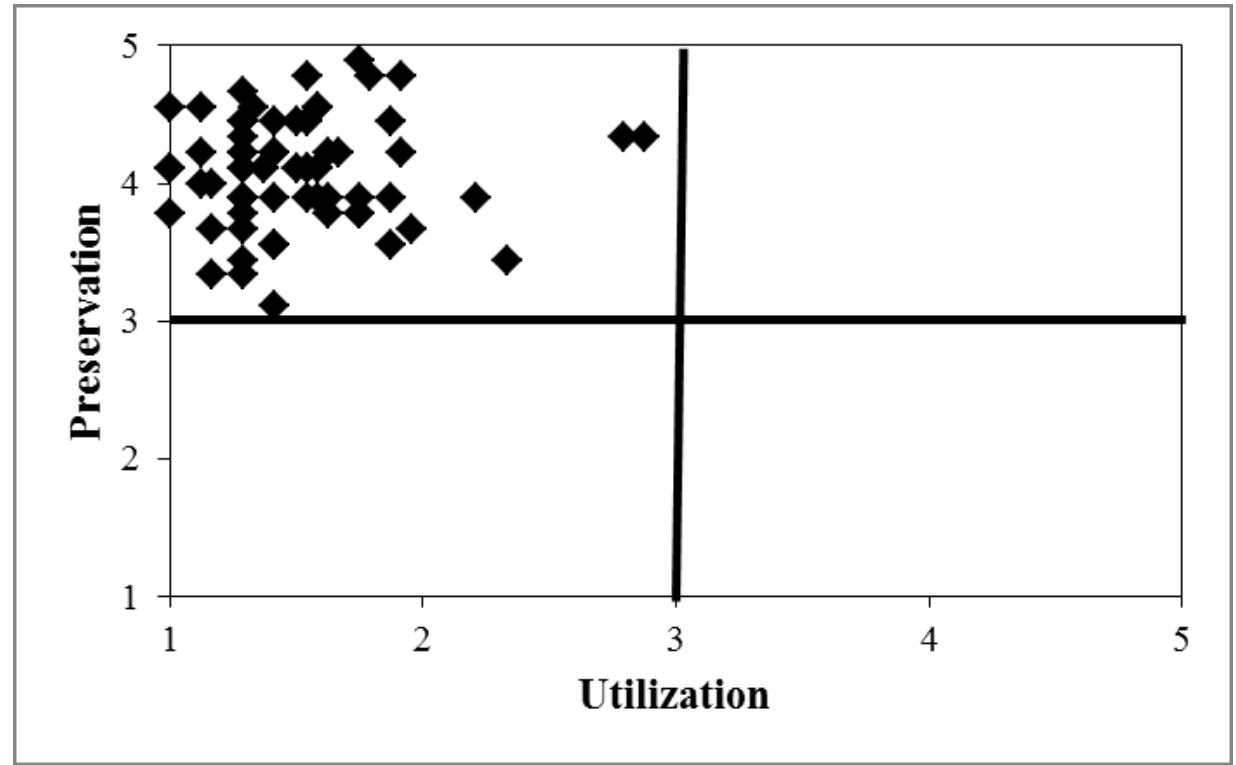

\section{Figure 5: Model of ecological values quadrant scores for pre-service biology teachers (São Paulo, Brazil).}

In short, basic education students are mostly placed at the $\mathrm{P}+\mathrm{U}$ - category, followed by $\mathrm{P}+\mathrm{U}+$, regardless their city location. However, all pre-service biology teachers were placed at $\mathrm{P}+\mathrm{U}$ - (Figures 3-5).

\section{Discussion}

It can be expected that students from coastal cities show a closer relation with marine and coastal environments when compared to students from cities located far from these areas. However, some investigations conducted in Brazil have been showing that it is not always true and, the relation is mostly based on utilitaristic bases, e.g. food, place to live, recreation (Katon, Towata, Berchez, Oliveira \& Ursi, 2013; Katon, Towata, Berchez \& Ursi 2014; Savietto, Katon, Towata, Berchez \& Ursi, 2014; Ursi \& Towata, 2012). The results of the present research complemented these data, since they highlight that most students, regardless their city location, showed pro-environmental positions, but a high percentage of students can also be found on $\mathrm{P}+\mathrm{U}+$ category (around 25\%), in which it can be classified someone with a strong desire to protect the environment, but at the same time believe that the primary purpose of nature is to benefit humans.

Towata and Ursi (2017) studied the same subject groups focused on the present research, however using a distinct approach, based on open answer questions. Their results were not similar in one aspect: differences were found between students from coastal and non-coastal city, since $57 \%$ of students from coastal city declared that they can establish a relationship with marine and coastal environments, while only $20 \%$ of students from a no-coastal city were able to do this relationship. Nevertheless, in both research, it was possible to detect the utilitaristic view of students, regardless their city location. 
Suzana URSI, Naomi TOWATA. Environmental perception about marine and coastal ecosystems: Evaluation through a research instrument based on model of ecological values

PROBLEMS

OF EDUCATION

IN THE $21^{\text {st }}$ CENTURY Vol. 76, No. 3, 2018

The comparison of the present study results and the ones of Towata and Ursi (2017) highlights the relevance of the variation on research methods to investigated EP in a wider perspective, since it was possible to detect differences on results when researchers used open answer questions or CEQ. It is common to use the qualitative and quantitative approaches separately, because their applicability is dependent on the issue and the question to be investigated. Both techniques are necessary and complementary to each other (Flick, 2014). According to these ideas, it is important to recognize CEQ as an additional instrument to EP evaluation, that can be used together with qualitative approaches.

This is the first article using CEQ for evaluated perceptions specifically about marine and coastal environments. In consequence, there are no previous research using this instrument. However, data obtained by Johnson and Manoli (2008; 2011), when they investigated students' Environmental Perception in general (using original TEC with situation more related to land ecosystems), is similar with the data observed in the present research to non-coastal city students, because, in both investigations, participants are placed in all quadrants, and mostly in the two related to pro-environmental perceptions $(\mathrm{P}+\mathrm{U}-$ and $\mathrm{P}+\mathrm{U}+)$.

The pro-preservation position of students, which was reported for both land and coastal environments, can be considered a positive result. However, it is important to deal with the proutilization position. By working with the concept of sustainable development, the Environmental Education programs could promote better models based on the wise use of resources, with concerns for equity and durability (Sauvé, 1996). As a consequence, the pro-utilization position could be minimized by educating the citizen to be more conscious about the use of resources.

Munoza, Bogner, Clement and Carvalho (2009) conducted a broad research with more than 6000 pre-service and in-service teachers in 16 countries in Europe and its neighborhood using the 2-MEV instrument (similar to TEQ). Their results suggested a major discrepancy between less and more developed countries with regard to the Utilization dimension. The authors hypothesize that countries with a lower economic standard might express less concern about overusing natural resources, as people focus their main concern on meeting their primary needs.

The present results did not corroborate this idea, since, even Brazil being a non-developed country, the pre-service teachers investigated showed a strong pro-environmental position, at least related to marine and coastal environments. However, it was conducted only a pilot test, with a modest sample and further studies are needed to complement the data. Another important thing to be considered is that the teacher's subject was a consistent source of variation within countries on Munoza, Bogner, Clement and Carvalho (2009) study. The present research investigated only biology teachers. It can be hypothesized that this group probably has the most pro-environmental profile when compared to other subject teachers. Therefore, different results could be found in Brazil if the sample included other groups of teachers.

\section{Conclusions}

The aim of the proposal for a new instrument research was reached since the present study showed that the Costal Environment Questionnaire (CEQ) could be useful on studies aiming better understanding of the perception about marine and coastal environments, through the evaluation of ecological values about these important ecosystems. CEQ can be applied on future studies to investigate the influences of an educational intervention (including Environmental Education programs) on the participants EP. However, the conducted research also highlights that EP is a very complex concept. Therefore, the best approach to understand it is the use of a variety of research methods, being CEQ an additional contribution to this process. The exclusive use of CEQ may limit the EP analysis. 
In addition, it was possible to detect, using CEQ, differences of the positions on the categories from Model of Ecological Values among the subject groups focused on this research because all biology pre-service teachers were located at $\mathrm{P}+\mathrm{U}+$ category, while basic education students were mainly distributed on $\mathrm{P}+\mathrm{U}+$ and $\mathrm{P}+\mathrm{U}$ - categories. An interesting research question for a future study arises from this result: Are pre-service teachers from other knowledge areas located at the same category of Model of Ecological Values when compared to biology preservice teacher?

Finally, based on the similarity of results obtained with CEQ for basic education students from coastal and non-coastal cities, we can suggest that the attitude of preservation related to an ecosystem does not depend only on the proximity to it. Maybe other factors, such as Environmental Education in School or living in a globally interconnected word, are more significant nowadays. It can be a good hypothesis to be investigated in future research, when the comparisons should be done with a larger sample then utilized in the present research.

\section{Acknowledgements}

The authors thank FAPESP-Fundação de Amparo à Pesquisa do Estado de São Paulo (BIOTA Program, Process 2013/50709-6) for financial support and CNPq-Conselho Nacional de Desenvolvimento Científico e Tecnológico for financial support and scholarship for the $\mathrm{PhD}$ student Naomi Towata. The authors also thank basic education students and pre-service biology teachers that participated in this research.

\section{References}

Aswani, S., Vaccaro, I., Abernethy, K., Albert, S., \& Pablo, J. F. (2015). Can perceptions of environmental and climate change in island. Communities assist in adaptation planning locally? Environmental Management, 56 (6), 1487-1501.

Babier, E. B. (2017). Marine ecosystem services. Current Biology, 27 (11), 507-510.

Bell, P. A., Greene, T. C., Fisher, J. D., \& Baum, A. (2001). Environmental Perception and Cognition in: Bell, P. A., Greene, T. C., Fisher, J. D., Baum, A., \& Bell, P. A. Environmental psychology. 5. Ed. Fort Worth, TX: Harcourt College Publishers.

Bogner, F. X. (1999). Empirical evaluation of an educational conservation programme introduced in Swiss secondary schools. International Journal of Science Education, 21 (11), 1169-1185.

Bogner, F. X. (2002). The influence of a residential outdoor programme to pupil's environmental perception. European Journal of Psychology of Education, 17 (1), 19-34.

Bogner, F. X., \& Wilhelm, M.G. (1996). Environmental perception of pupils. Development of an attitude and behavior scale. The Environmentalist, 16, 95-110.

Bogner, F. X., \& Wiseman, M. (1997a). Environmental perspectives of Danish and Bavarian pupils: towards a methodological framework. Scandinavian Journal of Educational Research, 41 (1), 53-71.

Bogner, F. X. \& Wiseman, M. (1997b). Environmental perception of rural and urban pupils. Journal of Environmental Psychology, 17 (2), 111-122.

Bogner, F. X., \& Wiseman, M. (1998). Environmental perception of Swiss and Bavarian pupils. Swiss Journal of Sociology, 24 (3), 547-566.

Bogner, F. X., \& Wiseman, M. (1999). Toward measuring adolescent environmental perception. European Psychologist, 4 (3), 139-151.

Bogner, F. X., \& Wiseman, M. (2004). Outdoor Ecology Education and Pupil's environmental perception in preservation and utilization. Science Education International, 15 (1), 27-48.

Covi, M. P., \& Kain, D. J. (2015). Sea-level rise risk communication: Public understanding, risk perception, and attitudes about information. Environmental Communication, 10 (5), 612-633.

De Juan, S., Gelcich, S., \& Fernandez, M. (2017). Integrating stakeholder perceptions and preferences on ecosystem servicer in the management of coastal areas. Ocean \& Coastal Management, 136, $38-48$. 
Suzana URSI, Naomi TOWATA. Environmental perception about marine and coastal ecosystems: Evaluation through a research instrument based on model of ecological values

\section{PROBLEMS \\ OF EDUCATION \\ IN THE $21^{\text {st }}$ CENTURY Vol. 76, No. 3, 2018 \\ 404}

Dunlap, R. E. (1975). Sociological and social-psychological perspectives on environmental issues: A bibliography. Exchange Bibliography No. 916. Monticello, IL: Council of Planning Librarians.

Dunlap, R. E., Van Liere, K. D. Mertig, A. G., \& Jones, R. E. (2000). Measuring endorsement of the New Ecological Paradigm: A revised NEP scale. Journal of Social Issues, 56 (3), 425-442.

Fauville, G. (2017). Questions as indicators of ocean literacy: students' online asynchronous discussion with a marine scientist. International Journal of Science Education, 39 (16), 1-20.

Flick, U. (2014). An introduction to qualitative research. London: Sage.

Fox, C. H., O’Hara, P. D., Bertazzon, S., Morgan, K., Underwood, F. E., \& Paquet, P. C. (2016). A preliminary spatial assessment of risk: Marine birds and chronic oil pollution in Canada's Pacific coast. Science of the Total Environment, 573, 799-809.

Ghilardi-Lopes, N. P., Turra, A., Buckeridge, M. S., Silva, A. C., Berchez, F. A. S., \& Oliveira, V.M. (2015). On the perceptions and conceptions of tourists with regard to global environmental changes and their consequences for coastal and marine environments: A case study of the northern São Paulo State coast, Brazil. Marine Policy, 57, 85-92.

Jacobs, S., Sioen, I., Pieniak, Z., Henauw, S. D., Maulvault, A. L., Reuver, M., Fait, G., Cano-Sancho, G., \& Verbeke, W. (2015). Consumers' health risk-benefit perception of seafood and attitude toward the marine environment: insights from five European countries. Environmental Research, 143 (b), 11-19.

Johnson, B., \& Manoli, C. C. (2008). Using Bogner and Wiseman's Model of Ecological Values to measure the impact of an earth education programme on children's environmental perceptions. Environmental Education Research, 14 (2), 115-127.

Johnson, B., \& Manoli, C. C. (2011). The 2-MEV scale in the United States: A measure of children's environmental attitudes based on the Theory of Ecological Attitude. The Journal of Environmental Education, 42 (2), 84-97.

Katon, G. F., Towata, N., Berchez, F. A. S., Oliveira, V. M., \& Ursi, S. (2013). Percepção de estudantes que vivem distantes do litoral sobre o Ambiente Marinho [Perception of students living far from the coast about the Marine Environment]. Revista de Investigación y Experiencias Didácticas, $v$. extra, 1342-1347.

Katon, G. F., Towata. N., Berchez, F. A. S., \& Ursi, S. (2014). Percepção de Ambientes Marinhos e Costeiros: uma visão de estudantes de um curso técnico em meio ambiente [Perception of Marine and coastal environments: A view of students from an environment technical course]. Revista de Ensino de Biologia da Associação Brasileira de Ensino de Biologia, 7, 2648-2660.

Krelling, A. P., Williams, A. T., \& Turra, A. (2017). Differences in perception and reaction of tourist groups to beach marine debris that can influence a loss of tourism revenue in coastal areas. Marine Policy, 83, 87-99.

Lundin, C. G., \& Lindén, O. (1993). Coastal ecosystem: attempts to manage a threatened resource. Ambio, 22, 468-473.

Michael, H. A., Post, V. E. A., Wilson, A. M., \& Werner, A. D. (2017). Science, society, and the coastal groundwater squeeze. Water Resources Research, 53 (4), 2610-2617.

Munoza, F., Bogner, F. X., Clement, P., \& Carvalho, G. S. (2009). Teachers' conceptions of nature and environment in 16 countries. Journal of Environmental Psychology, 29 (4), 407-413.

Nel, H. A., Hean, J. W., Noundou, X. S., \& Froneman, P.W. (2016). Do microplasticloads reflect the population demographics along the southern African coastline? Marine Pollution Bulletin, 115 (1-2), 115-119.

Pedrini, A. de G., Brotto, D. S., Lopes, M. C., Ferreira, L. P., \& Ghilardi-Lopes, N. P. (2013). Percepções sobre Meio Ambiente e o mar por interessados em Ecoturismo Marinho na Área de Proteção Ambiental Marinha de Armação de Búzios, Rio de janeiro, RJ, Brasil [Perceptions about the environment and the sea by people interested in marine ecotourism on the marine environmental protection area of Armação de Búzios, Rio de Janeiro, RJ, Brazil]. Pesquisa em Educação Ambiental, 8 (2), 25-38.

Rubio-Cisneros, N., Aburto-Oropeza, O., Jackson, J., \& Ezcurra, E. (2017). Coastal exploitation throughout Marismas Nacionales Wetlands in northwest Mexico. Tropical Conservation Science, $10,1-26$.

Rustici, M., Ceccherelli, G., \& Piazza, L. (2017). Predator exploitation and sea urchin bistability: Consequence on benthic alternative states. Ecological Modelling, 344, 1-5.

Sauvé, L. (1996). Environmental education and sustainable development: a further appraisal. Canadian Journal of Environmental Education, 1, 7-34. 
Suzana URSI, Naomi TOWATA. Environmental perception about marine and coastal ecosystems: Evaluation through a research instrument based on model of ecological values

Savietto, S. F., Katon, G. F., Towata, N., Berchez, F. A. S., \& Ursi, S. (2014). Ambientes marinhos e costeiros: qual a percepção de estudantes de escolas do litoral norte de São Paulo? [Marine and coastal environments: what is the perception of students from schools located on the North coast of São Paulo?]. Revista de Ensino de Biologia da Associação Brasileira de Ensino de Biologia, 7, 6746-6757.

Schultz, P. W. Shriver, C. Tabanico, J. J., \& Khazian, A. M. (2004). Implicit connections with nature. Journal of Environmental Psychology, 24 (1), 31-42.

Sheaves, M. (2017). How many fish use mangroves? The $75 \%$ rule an ill-defined and poorly validated concept. Fish and Fisheries, 18 (4), 778-789.

Towata, N., \& Ursi, S. (2017). Perception and connectedness with marine and coastal environments: the perspective of basic education and undergraduate students from two Brazilian cities. Conexão Ciência, 12 (2), 256-363.

Tran, L. X., \& Fischer, A. (2017). Spatiotemporal changes and fragmentation of mangroves and its effects on fish diversity in Ca Mau Province (Vietnam). Journal of Coastal Conservation, 21 (3), 355368 .

Ursi, S., \& Towata, N. (2012). Relation between marine environment and quotidian: what are the spontaneous concepts of students? In: Conference Proceedings - 10th Annual Hawaii International Conference on Education, Honolulu, 1758-1764.

Ursi, S., Towata, N., Saito, L. C., Barbosa, P. P., Macedo, M., Viana, A. O., \& Berchez, F. A. S. (2016). Influências do Projeto Trilha Subaquática na Percepção de estudantes sobre ambientes marinhos e costeiros [Influences of the underwater trail project on student perception about marine and coastal environments]. Revista de Ensino de Biologia da Associação Brasileira de Ensino de Biologia, 9, 3524-3536.

Uyarra, M. C., \& Borja, Á. (2016). Ocean literacy: a 'new' socio-ecological concept for a sustainable use of the seas. Marine Pollution Bulletin, 104, 1-2.

Wiseman, M., \& Bogner, F. X. (2003). A higher-order model of ecological values and its relationship to personality. Personality and Individual Differences, 34 (5), 783-794.

White, A. V. T. (1977). Guidelines for fields studies in Environmental Perception. Paris: UNESCO/MAB.

Yasué, M. L., Kaufman, L., \& Vincent, A. C. J. (2010). Assessing ecological changes in and around marine reserves using community perceptions and biological surveys. Aquatic Conservation: Marine and Freshwater Ecosystems, 20 (4), 407-418.

Received: March 07, 2018

Accepted: June 04, 2018 \begin{tabular}{|l} 
PROBLEMS \\
OF EDUCATION \\
IN THE 21 $1^{\text {st }}$ CENTURY \\
Vol. 76, No. 3, 2018 \\
\hline 405
\end{tabular}

\begin{tabular}{|ll|}
\hline Suzana Ursi & PhD, Professor, Institute of Bioscience, University of São Paulo, Rua do \\
& Matão, 277 - São Paulo/SP - Brazil. \\
& E-mail: suzanaursi@usp.br \\
\hline Naomi Towata & PhD Student, Institute of Bioscience, University of São Paulo, Rua do Matão, \\
& 277 - São Paulo/SP - Brazil. \\
E-mail: ntowata@usp.br
\end{tabular}

